\title{
ALBERTA GAS IN UNITED STATES MARKETS: CANADIAN AND AMERICAN PERSPECTIVES ON COMPETITION, CONSTITUTIONAL AND CONTRACT ENFORCEMENT ISSUES
}

\section{KEMM YATES and PATRICK J. KEELEY*}

The authors discuss regulatory issues of particular importance and topicality. Included are considerations of the question of whether the pricing pool arrangements under the Alberta Natural Gas Marketing Act, as amended in 1991, may be challenged as violations of the Competition Act (Canada) or the Sherman Antitrust Act (United States) or the Free Trade Agreement between Canada and the United States. The constitutional validity of the amended Alberta Natural Gas Marketing Act is reviewed. The effects of decisions of state regulatory tribunals on contracts for purchase and sale of natural gas are examined in the context of the United States Constitution.

\section{TABLE OF CONTENTS}

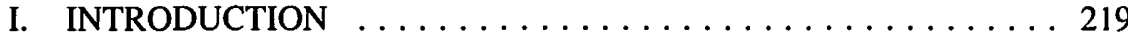

II. FACTUAL BACKGROUND . . . . . . . . . . . . . . . . 220

III. ALBERTA NATURAL GAS MARKETING ACT . . . . . . . . 225

IV. THE CANADIAN CONSTITUTIONAL VALIDITY

OF THE NATURAL GAS MARKETING ACT . . . . . . . . 226

V. UNITED STATES CONSTITUTIONAL ISSUES . . . . . . . 232

VI. CANADIAN COMPETITION LAW CONSIDERATIONS . . . . . . 237

VII. UNITED STATES ANTITRUST CONSIDERATIONS . . . . . . . . . 242

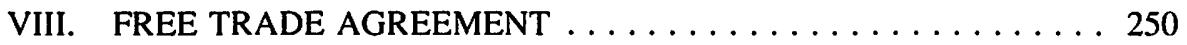

IX. CONCLUSION $\ldots \ldots \ldots \ldots \ldots \ldots \ldots \ldots \ldots \ldots \ldots$

\section{INTRODUCTION}

The idea of selling Alberta gas in United States markets dates from shortly after the Leduc No. 1 discovery in 1947. In the 1950s, pipeline projects were conceived that resulted in actual export sales into California and the United States midwest. More recently, Canadian gas has found its way into markets in the northeastern United States, first through the initial project of Boundary Gas, Inc. and later the Alberta Northeast Gas Export Project involving the construction of the Iroquois Gas Transmission System. For more than forty years, then, the natural gas industry has been dealing with some aspect or other of international gas trade. There have been new ideas for projects and pipelines. There has been governmental regulation and deregulation of prices and markets. Surplus test requirements were tightened, then relaxed. In 1989, the Canada-United States Free

C. Kemm Yates is a partner of the law firm of Milner Fenerty of Calgary and Edmonton. Patrick J. Keeley is a partner of the law lirm of Fulbright \& Jaworski which has offices in Washington, D.C., Houston, New York, Los Angeles, and elsewhere. Milner Fenerty and Fulbright \& Jaworski have formed an association to facilitate serving the needs of their respective energy industry clients in international transactions. The assistance of Douglas E. Crowther, Jodi L. Cohen and Michael P. Goggin in preparing this article is gratefully acknowledged. 
Trade Agreement added a new dimension to the contractual and regulatory issues which had previously characterized continental gas trade.

In spite of the Free Trade Agreement, the industry focus has increasingly been on the actions of regulators and the impacts of those actions on freely negotiated contracts. For example, in a hearing relating to the Iroquois project, the National Energy Board dealt with the major issue of the manner in which actions of state utility regulators could affect the operation of the purchase and sale contracts which underpinned the construction of the proposed expansion facilities of TransCanada PipeLines Limited and the Iroquois pipeline itself.' Facilities approvals having been obtained, the project has faded into the background, probably temporarily, while California has come to the fore.

The present actions and reactions of the Public Utilities Commission of California, the governments of Canada, Alberta and the United States, and of producers and pipelines raise political, legislative, regulatory and litigious issues which must be resolved expeditiously. There are constitutional and competition law issues involved that affect the enforceability of contracts to sell Alberta gas in any United States markets. In Canada, one constitutional issue relates to the validity of the Natural Gas Marketing Act ${ }^{2}$ of Alberta. In the United States, a constitutional issue involves the doctrine of preemption. In both countries, the competition issues revolve around the operation of the Alberta producer "pool" arrangement for pricing natural gas. Meanwhile, the Free Trade Agreement looms over the actions of legislators and regulators on both sides of the border.

\section{FACTUAL BACKGROUND}

The legal issues are germane to sales of Canadian gas in all United States markets. The present focus of the debate, however, is California, a situation that has been precipitated by the actions of the public utilities commission of that state. The California facts can therefore be used to analyze the issues, recognizing that the legal concepts have much broader application than to California alone.

The historical background is complicated. Pacific Gas \& Electric Company ("PG\&E") is a utility providing natural gas service to more than three million customers in northern and central California. PG\&E is regulated by the Public Utilities Commission of California ("CPUC"). In the late 1950s, to ensure that it could serve its expanding market requirements, PG\&E conceived the Alberta-California Pipeline Project which involved the incorporation of Alberta and Southern Gas Co. Lid. ("A\&S"), Alberta Natural Gas Company Ltd. ("ANG") and the Pacific Gas Transmission Company ("PGT") to combine to purchase gas in Canada, to construct the requisite facilities to transport Canadian gas to California, and to actually transport the gas from Alberta to California. In Canada, A\&S (a wholly-owned subsidiary of PG\&E) has acted as an aggregator, contracting to buy gas from producers. It has obtained and maintained the federal and provincial 
authorizations necessary to remove gas from Alberta and export gas from Canada. It has also organized transportation within Canada, contracting to ship gas through the facilities of the NOVA Corporation of Alberta to the Alberta border from which point the facilities built and owned by ANG (in which PGT holds a 49 percent interest) are used to ship the gas to the United States border at Kingsgate, British Columbia. At that point, A\&S sells the gas to PGT (a wholly-owned subsidiary of PG\&E) pursuant to a gas sales contract which contains delivery volume stipulations, provides for market-oriented pricing of the gas supply, and contains a take-or-pay provision at the fifty-percent level. PGT owns and ships the gas through its own facilities to the California border where it is sold to PG\&E under a service agreement and rate schedule which are subject to the jurisdiction of the United States Federal Energy Regulatory Commission ("FERC"). PG\&E made a contractual commitment to PGT to purchase the gas on an equitable, annual equivalent percentage basis with its purchases of gas from its other suppliers, provided that the price and cost relationship of the supplies and all applicable laws and regulations allowed such an arrangement to take place. PG\&E sells the Canadian gas to its customers in accordance with rate schedules and service conditions approved by the CPUC. ${ }^{3}$

In 1988, A\&S applied to the National Energy Board of Canada ("NEB" or the "Board") for an amendment to its natural gas export licence to extend the term of that licence and to increase the authorized term quantity. A\&S argued that its application should be granted in the light of PG\&E's projected market requirements, the availability of marketcompetitive prices to the A\&S producers, and the dedicated reserves under the extended contracts and development contracts which it had negotiated to support the application. After a hearing which included representations made to the NEB by A\&S, PG\&E and the CPUC relating to the California market, gas supply, contracts and other matters, the NEB in 1989 granted a new licence ${ }^{5}$ which effectively extended the A\&S licence through October 31, 2005. In its decision, the NEB noted that the one billion cubic feet per day of Canadian gas that is channelled to California through A\&S and PGT accounts for between 40 and 50 percent of PG\&E's annual requirements. ${ }^{6}$

Since 1988, Canadian producers have consistently opposed any action by the CPUC that would interfere with pre-existing contractual relationships. They point to the reliability and stability of supply that has been provided to California consumers through such long-term contractual arrangements and to the fact that construction of additional pipelines from Canada to California would better serve to promote competition without running the risk of violating the Free Trade Agreement ("FTA").

CPUC actions have included various efforts to promote competition by maximizing access to firm interstate pipeline capacity. The CPUC initiated a proceeding (the

On September 5, 1991. TransCanada PipeLines Limited announced that it had signed a letter of intent which could lead to its purchase from PG\&E of the entire interests of PG\&E in PGT and ANG. Purchase of A\&S was also being discussed. As of December 19, 1991, no sale had been completed. Licence GL-99.

Licence GL-111.

National Energy Board Reasons for Decision In the Matter of Alberta and Southem Gas Co. Ltd., GH-5-88, May 1989, at 10. 
"capacity brokering proceeding") to determine the proper manner in which to "broker" firm transportation capacity rights held by utilities on PGT, El Paso Natural Gas Company and Transwestern Pipeline Company to end-users, producers and marketers. ${ }^{7}$ In the capacity brokering proceeding the CPUC built upon the foundation that it laid on September 25, 1990 when it approved final procurement restructuring rules in D90-090-89 (the "Procurement Decision").

The Procurement Decision, which was intended to alter the purchasing practices of California natural gas utilities by reducing the portion of the California market for which utilities may procure gas supply, is designed to function as an interim measure "pending final resolution" of capacity brokering issues in California. ${ }^{8}$ While the Procurement Decision seeks to open the California natural gas market to increased competition, it also recognizes the viability of existing obligations arising under Canadian gas supply contracts. Specifically, the Procurement Decision incorporates the terms of the "Access Agreement," an interim settlement document entered into by the CPUC, the Alberta Petroleum Marketing Commission ("APMC") on behalf of the Alberta Government, and other interested parties. This agreement, the terms of which are to remain in effect until August 1, 1994, provides that 250 MMcfd of capacity on the PGT system is to be purchased by PG\&E customers from contracted-for Canadian supply. ${ }^{9}$ At the same time, however, the CPUC stated in the Procurement Decision that such a provision may not "go far enough" to "open up access," and that, in the "view" of the CPUC, the Canadian contracts of PG\&E should be renegotiated by December 31, 1991. ${ }^{10}$

The Procurement Decision is a clear attempt by the CPUC to respond to what it sees to be the anti-competitive effect of capacity constraints on the interstate pipeline systems serving California. To this end, the CPUC seeks to provide pipeline access to customers, producers, and marketers, and to effect a renegotiation of contracts serving to constrain capacity. Yet, the impact of this decision upon Canadian producers may be very significant. Canadian producers have asserted that the A\&S gas purchase contracts have been "singled out" for discriminatory treatment while contracts containing the same terms, but entered into by United States producers, are left intact." According to Canadian producer interests, such disparate treatment violates an express command of the FTA, specifically, the fundamental premise to treat energy products from both countries in an equal manner so that the country of origin of the good is rendered irrelevant. ${ }^{12}$ The Canadian producers have additionally noted that state commissions, like the FERC, are bound to uphold and to further the provisions of the FTA. ${ }^{13}$

7. PG\&E presently holds virtually all of the rights to firm transportation on PGT, while another Califomia utility plays a similarly dominant role on the El Paso system.

x. Procurement Decision at 46.

9. $\quad$ Ibid. at 32 .

11. $\quad$ lbid. at 59.

11. See Second-Round Comments of the Canadian Producers Group (Aug. 15, 1990) at 8-9.

12. Ibid. at 9 .

13. Ibid. at 10. The producers cite Article 502 of the FTA to support this proposition. Article 502 reads: The provisions of this chapter regarding the treatment of like, directly competitive or substitutable goods shall mean, with respect to a province or a state, treatment no less favourable than the most favourable treatment accorded 
On August 19, 1991, Administrative Law Judge ("ALJ") Kim Malcolm of the CPUC issued a proposed decision on capacity brokering. The CPUC process requires an ALJ to propose a decision to the full Commission which may then confirm, reject or amend that decision. In its Decision 91-11-025 ("Capacity Brokering Decision") issued November 4, 1991, the CPUC confirmed virtually all significant aspects of the proposed decision, reviewing the issue of access to Canadian supplies over the PGT line, finding that PG\&E has no contractual obligations which would preclude access over PGT, rejecting the submissions of Canadian groups that the contracts between A\&S and Canadian producers should be honoured, and refusing to honour the Access Agreement which was previously applauded by the CPUC in the Procurement Decision. ${ }^{14}$

In response to the actions of the CPUC, the Canadian Petroleum Association ("CPA") applied to the NEB on May 29, 1991 for review of the 1989 decision of that Board to extend the A\&S gas export licence. The stated goal of the CPA in taking this step is to make the CPUC comply with the principle that the marketplace should determine the supply, demand and price for natural gas. In the process, however, the CPA is also alleging that the CPUC actions are contrary to the FTA for the same reasons as were cited by the Canadian producer group to the CPUC, namely that the CPUC actions effect an import restriction on Canadian gas and, further, violate the requirement that Canadian gas be taken on terms no less favourable than the most favourable arrangement within the consuming state.

Apparently also in response to the CPUC actions, the Alberta Government proclaimed legislation on July 3, 1991 which amended the Natural Gas Marketing Act ("NGMA") by adding section $9.1^{15}$ which allows that government to designate any netback pricing

by such province or state to any like, directly competitive or substitutable goods, as the case may be, of the Party of which it forms a part.

As noted by the producer group, such a provision arguably imposes a greater obligation upon state agencies than is imposed upon the FERC, as the Article speaks of according treatment to foreign goods equivalent to the most favourable treatment bestowed upon domestic goods.

Decision 91-11-025 of the Public Utilities Commission of the State of California. Order Instituting Rulemaking into natural gas procurement and reliability issues. R.88-08-018 (Filed August 10. 1988). Order Instituting Rulemaking on the Commission's own motion to change the structure of gas utilities' procurement practices and to propose refinements to the regulatory framework for gas utilities. R.90-02-008 (Filed February 2, 1990). See Section X. Access to Canadian Gas Supplies. Natural Gas Marketing Amendment Act. 1991. S.A. 1991. c. 25, proclaimed on July 3, 1991. Section 9.1 reads:

9.1(1) In this section,

(a) 'continuation period', in relation to a netback pricing agreement to which a designated shipper is a party, means the period commencing on the effective date of the designation order applicable to the shipper and ending on the date on which this section ceases to apply to the shipper by retson of subsection (5);

(b) 'designated shipper' means a shipper designated by an order under subsection (2) as a shipper to whom this section applies;

(c) 'designation order', in relation to a designated shipper. means the order under subsection (2) designating that shipper as a shipper to whom this section applies; 
agreement as continuing to be binding on the parties thereto notwithstanding any expiration or termination of the agreement by its terms or otherwise. The new legislative provisions empower the Lieutenant Governor in Council to designate that section 9.1 applies to any shipper that, in the opinion of the Lieutenant Governor in Council, "is

(d) 'effective date', in relation to a designation order, means the date on which the order is made effective;

(e) 'netback pricing agreement' means an agreement between a shipper and a producer, whether contained in their producer-shipper contract or not, providing for a netback pricing formula with respect to netback gas sold to the shipper under the producer-shipper contract, and includes a contract that varies or amends that agreement.

(2) The Lieutenant Governor in Council may, by order, designate a shipper as a shipper to whom this section applies if the Lieutenant Governor in Council is of the opinion that the shipper is affiliated with, or is otherwise influenced in favour of, a major purchaser of gas acquired by that shipper.

(3) A designation order may be made effective as of a date prior to the day on which it is made but not earlier than June 3, 1991.

(4) If a designation order is made in respect of a shipper and the shipper is a party to a netback pricing agreement in effect on the effective date of the designation order.

(a) the netback pricing agreement, in the form in which it stood on the effective date, remains binding on the parties during the continuation period of the agreement, notwithstanding any expiration or termination of the agreement occurring during the continuation period, and

(b) after the date on which the designation order is made and during the remainder of the continuation period of the agreement, the designated shipper shall not, except with the approval of the Commission and subject to any conditions prescribed by the Commission, purchase gas for resale unless the gas is purchased under a producer-shipper contract that was in effect on the effective date, whether or not the price to be paid under the contract is determined in accordance with a netback pricing agreement.

(5) A netback pricing agreement to which subsection 4(a) applies may be amended during its continuation period if the amendment agreement is approved by the commission, with or without conditions.

(6) This section ceases to apply to a designated shipper and the netback pricing agreements to which the designated shipper is a party

(a) on a date determined in accordance with the regulations following a vote of the producers who are parties to the agreements conducted in accordance with the regulations and favouring the termination of the application of this section to the shipper and the agreements,

(b) on the revocation of the designation order, or

(c) at any other time and in any other circumstances provided for in the regulations.

(7) The Lieutenant Governor in Council may make regulations

(a) respecting a vote of producers for any purpose under this section;

(b) respecting the time at which and the circumstances in which this section ceases to apply to a designated shipper and to the netback pricing agreements to which the designated shipper is a party:

(c) respecting any other mater arising under this section.

(8) If this section applies to a netback pricing agreement, it applies notwithstanding anything in that agreement or in the producer-shipper contract or any other contract or arrangement between the producer and the designated shipper who are parties to the agreement or any purported termination of the agreement.

(9) A person who contravenes this section or a regulation under this section is guilty of an offence.

(10) This section is repealed on November 1, 1994 unless it is sooner repealed by Proclamation. 
affiliated with, or is otherwise influenced in favour of, a major purchaser of gas acquired by that shipper." After proclamation of the legislation, the Alberta government declared A\&S to be a "designated shipper"16 and established a process to apply to restructuring of the contracts between A\&S and producers. ${ }^{17}$

The effect of the decreed continuation of any netback pricing agreement is arguably to establish a price for natural gas being exported from Canada at the price extant in the agreement when the designation order becomes effective. Such an argument not only raises the issue of the constitutional validity of section 9.1 but precipitates a reconsideration of the validity of the entire NGMA from a constitutional perspective. It also necessitates a look at the obverse of the coin - the validity of the actions of the CPUC under the United States Constitution. Further issues relate to the potential for attack under Canadian and United States anti-competition laws of actions undertaken by parties pursuant to the NGMA and regulations. The overall impact of the FTA on the situation is also relevant.

\section{ALBERTA NATURAL GAS MARKETING ACT}

The NGMA is a child of deregulation. It was enacted in 1986 in response to concerns in respect of the determination of price components in netback-priced gas contracts. It was also intended to deal with natural gas pricing problems created by deregulation. ${ }^{18}$ Part 2 of the NGMA sets out the mechanism which was devised to give producers some influence over the price at which the gas they sell to shippers is resold by those shippers.

Section 9 of the NGMA prohibits a shipper of "netback gas" from cither removing gas from Alberta for resale to another person or delivering that gas in Alberta for resale to another person unless the APMC has made a finding of producer support in relation to that "netback gas." "Netback gas" is defined as:

\footnotetext{
... marketable gas sold and delivered pursuant to producer-shipper contracts under which the same shipper is the buyer, where the price payable to the producers for gas so delivered is calculated in accordance with a netback pricing formula, but does not include marketable gas sold and delivered pursuant to at producer-shipper contract under which the producer's obligation to deliver gas under the contract is preconditioned on his consent to the actual resale price or prices used in the netback pricing formula. ${ }^{19}$
}

Paragraph $8(1)(f)$ of the NGMA defines "shipper" as "the buyer under a producershipper contract." "Producer-shipper contract," in turn, is defined in $\mathrm{s.} 8(1)(\mathrm{e})$ as "a gas contract relating to the first sale and delivery of: (i) gas after it is first recovered from a well, if the gas is marketable gas at the time it is so recovered, or (ii) gas after it first

16. Alberta Order in Council 489/91, July 18. 1991.

17. Alberta Regulation 263/91 filed July 18, 1991; Alberta Petroleum Marketing Commission, Commission Directive. September 23. 1991.

ix. For more detail on the NGMA. sec C.D. Hunt and A.R. Lucas, eds., Canada Energy Law Senice' Alberta, (Toronto: Richard de Boo Publishers, 1990) at 30-127ff.

14. NGMA, s. 8(1)(b). 
becomes marketable gas, in any other case and includes a gas contract that is deemed by the regulations to be a producer-shipper contract for purposes of [Part 2]."

The APMC is required to issue a finding of "producer support" where it determines that the shipper has, through the prescribed procedures, obtained the prescribed minimum degree of support from producers. ${ }^{20}$ The prescribed procedures are comprised of a balloting system which requires the shipper to solicit ballots from all producers on the question of whether each producer approves or disapproves of the price at which the shipper proposes to purchase its gas supplies or the mechanism which it proposes for the determination of that price. The prescribed procedures do not require, nor do they authorize, activities such as consultation or communication among the producers concerning how they intend to vote. There appears to be nothing in the NGMA or in the Natural Gas Marketing Regulation"1 ("NGMR") requiring producers to treat the balloting process as secret, although they may do so in practice.

The NGMA contemplates the establishment of a common price or a common pricing mechanism for all "netback gas," but neither the NGMA nor the NGMR speak to matters such as the allocation of purchases among producers. Consequently, there is nothing to require or authorize a commitment by a shipper to purchase a specified portion of its total purchases from a particular producer.

Under the contracts which presently exist, A\&S is a "shipper" purchasing "netback gas" from producers in Alberta and is subject to the requirement of obtaining a finding of "producer support" under section 9. The price for the sale from PGT to PG\&E in California is negotiated and Alberta producers vote pursuant to the procedures established by the NGMA and the NGMR to accept or reject the netback price in their agreements with A\&S. The netback agreement between $A \& S$ and Alberta producers would have expired on July 31,1991 had it not been extended by the Alberta enactment of section 9.1 of the NGMA and the declaration of A\&S as a "designated shipper."

\section{THE CANADIAN CONSTITUTIONAL VALIDITY OF THE NATURAL GAS MARKETING ACT}

It is now accepted that under the Constitution Act, $1867^{22}$ interprovincial and international trade and commerce are matters within the exclusive legislative jurisdiction of the Federal government while provincial power extends over intraprovincial trade and commerce under "property and civil rights in the province." ${ }^{23}$ The enactment of section 92A of the Constitution Act, 1867 extended provincial legislative jurisdiction over

20. NGMA, s. 9(2)

21. Natural Gas Marketing Regulation. Alberta Regulation 358/86, as amended. Paragraph 10(6) of the Natural Gas Marketing Regulation states that "nothing in this Regulation precludes a shipper from conducting an informal poll to obtain the views of some or all of his producers in order to assist him in forecasting the result of a vote under this section if one were held."

2. $\quad$ (U.K.) 30 \& 31 Vict., c. 3 [hereinafter the "Constitution Act, 1867"].

23. See P.W. Hogg, Constitutional Law of Canada, 2nd ed. (Toronto: The Carswell Company Limited, 1985) at $440 \mathrm{fr}$. 
interprovincial trade in natural resources. By virtue of subsection $92 \mathrm{~A}(2)$, provincial legislation can affect interprovincial gas trade provided that it does not discriminate in price or supply. However, no similar expansion of provincial jurisdiction has occurred in respect of international trade. ${ }^{24}$ In considering the question of whether the NGMA, as amended, is within the constitutional jurisdiction of the provincial legislature, regard must be had to the words of Chief Justice Laskin of the Supreme Court of Canada:

\begin{abstract}
Where governments in good faith ... invoke authority to realize desirable economic policies, they must know that they have no open-ended means of achieving their goals when there are constitutional limitations on the legislative power under which they purport to act. They are entitled to expect that the Courts, and especially [the Supreme Court of Canada], will approach the task of appraisal of the constitutionality of social and economic programmes with sympathy and regard for the serious consequences of holding them ultra vires. Yet, if the appraisal results in a clash with the Constitution, it is the latter which must govern. ${ }^{25}$
\end{abstract}

A resolution of the question of whether Alberta possesses the constitutional power to enact section 9.1 of the NGMA requires first, an identification of the "matter" of the legislation and second, an allocation of that matter to the appropriate head of power under the Constitution Act, 1867.

The "matter" of a statute is most often described as its "pith and substance" but the courts variously make reference to the "true aim and purpose," the "leading feature" or the "subject matter." Regardless of the manner of description, the concept suggests that the first step in judicial review of a statute is to identify its dominant or most important characteristic. ${ }^{26}$

In most instances only marginal assistance can be gained from a review of the case authorities. For the most part, the determination of the "pith and substance" of a law is dependent upon the facts of each case. ${ }^{27}$ Nonetheless, it is worth briefly discussing the two leading decisions of the Supreme Court of Canada concerning the constitutional division of powers in the context of regulation of trade in natural resources.

The first case is Canadian Industrial Gas \& Oil Ltd. v. Government of Saskatchewan, ${ }^{28}$ which related to the constitutional validity of certain statutes enacted by the legislature of the province of Saskatchewan. The legislation was enacted following the sharp rise in the price of oil on the world market which occurred in 1973 (during the so-called Arab Oil Crisis), and it had the effect of subjecting production revenues to a "mineral income tax" and a "royalty surcharge" which effectively allocated to the 61 Can. Bar Rev. 715.

25. Central Canada Potash Co. Limited v. Government of Saskatchen'an, [1979] 1 S.C.R. 42 at 76 [hereinafter "Central Canada Potash"].

26. Hogg, supra, note 23 at 313.

27. Milk Board v. Bari Cheese Lid. (1990), 70 D.L.R. (4th) 595 at 603 (B.C.S.C) [hereinafter "Milk Board"].

2x. [1978] 2 S.C.R. 545 [hereinafier "CIGOL"]. 
provincial government the entire difference between the price received by producers at the well-head and the "basic well-head price," a statutory figure approximately equal to the price per barrel received by producers prior to the energy crisis.

Canadian Industrial Gas \& Oil Ltd. was a corporation engaged in the exploration and production of oil and natural gas from leases and royalty interests in Saskatchewan. Seeking to obtain a declaration of the invalidity of the Saskatchewan legislation, it lost both at trial and on appeal to the Court of Appeal. The majority of the Supreme Court of Canada, however, allowed the appeal after concluding that the taxation scheme was ultra vires the Saskatchewan legislature since it constituted an indirect export tax, meaning that it was beyond the ambit of the direct taxation power allocated to the provinces under subsection 92(2) of the British North America Act. ${ }^{29}$ More importantly, the majority of the Court also considered that the legislation had the effect of setting a floor price for oil purchased for export from Saskatchewan and therefore was ultra vires as being legislation regulating interprovincial and international trade. Mr. Justice Martland wrote:

In considering [the issue of whether the legislation regulates trade and commerce in a prohibited fashion] the important fact is, of course, that practically all of the oil to which the mineral income tax or the royalty surcharge becomes applicable is destined for interprovincial or international trade. Some of this oil is sold by producers at the well-head and thereafter transported from the Province by pipeline.

The company which has its own oil production transported from the Province must, if it is to avoid pecuniary loss, ultimately dispose of the refined product at a price which will recoup the amount of the levy. Thus, the effect of the legislation is to set a floor price for Saskatchewan oil purchased for export by the appropriation of its potential incremental value in interprovincial and international markets, or to ensure that the incremental value is not appropriated by persons outside the Province.

The purpose of the legislation under review was accurately defined by Chief Justice Culliton in the [Saskatclewan] Court of Appeal:

"There is no doubt in my mind that both the Mineral Income tax and the royalty surcharge
were imposed for one purpose, and one purpose only - to drain off substantial benefits that
would have accrued to the producers due to the sudden and unprecedented price of crude oil.

The means used to achieve this end are to compel a Saskatchewan oil producer to effect the sale of the oil at a price determined by the Minister.... Provincial legislative authority does not extend to fixing the price to be charged or received in respect of the sale of goods in the

2\%. This aspect of the case would most probably be decided differently today in view of subsection 92A(4) of the Constitution ACl. 1867 which empowers the provinces to raise "money by any mode or system of taxation." i.e. direct or indirect, in respect of, inter alia, non-renewable natural resources. 
export market. It involves the regulation of interprovincial trade and trenches upon s. 91(2)

of the British North America Act. ${ }^{.30}$ |emphasis added]

This decision has apparent applicability to section 9.1 of the NGMA, and arguably to the NGMA itself. While the addition of section 9.1 purports to allow the Alberta government to make the legislation applicable to any natural gas aggregator with a downstream marketing affiliate, in fact $A \& S$ is the only aggregator that would fit that description and is the only aggregator that has been so designated. With A\&S declared to be a "designated shipper," all of the Alberta natural gas to be exported to California under long-term contracts is affected. The effect of the amended legislation is therefore arguably to fix or at least support the export price for that gas, at least until the producers, rather than A\&S, determine otherwise. Prior to the introduction of the amending legislation in the Alberta legislature, government "spokesmen" were quoted as saying that the intention was to preserve a pricing mechanism which determines the Alberta sale price on the basis of the market price for gas in California and that the government sees the underlying issue as being "...where the price of gas is determined - in the market place in California, or here where the gas is produced, ... [W]e think it should be priced in California." ${ }^{31}$ If this sort of statement found its way into evidence, it would leave little room for a court to conclude that the proposed amendments would have a purpose other than to fix or support the price for natural gas in the international export market.

Since the amending legislation does not attempt to set the export price expressly, it could (and no doubt will) be vigorously argued that the amendments are within provincial legislative jurisdiction. It is clear, however, that a court can look through any scheme in order to strike down attempts by provinces to do indirectly what they cannot do directly. ${ }^{32}$ It is also clear law that, in answering jurisdictional questions, a court must have regard for the true nature and character of a legislative scheme and for its actual effects. $^{33}$

The second case, Central Canada Potash, arose from an attempt by the Government of Saskatchewan in the late 1960s to proration production of potash in response to depressed world potash prices. In an effort to alleviate overproduction, Saskatchewan promulgated the Potash Conservation Regulations ${ }^{34}$ pursuant to The Mineral Resources $A c t^{35}$. At the time the Regulations came into effect, virtually all of the potash produced in Saskatchewan was sold outside the province and over sixty percent was sold to purchasers in the United States.

Under the initial prorationing scheme, each producer was permitted to produce and sell forty percent of its productive capacity. Only after every potash producer in

C. Donville, "Alberta takes steps to resist pressure on natural gas prices" The Glohe and Mail 20 April 1991) B-3.

Reference Re Agricultural Products Marketing Act. [1978] 2 S.C.R. 1198 at 1291-1292.

Milk Board, supra, note 27 at 603.

Sask. Reg. $287 / 69$ [hereinafter Regulations].

R.S.S. 1965 , c. 50. 
Saskatchewan had reached that level could a producer seek supplementary authorization for increased production and sales. The scheme was subsequently replaced by a much stricter "flat" scheme under which: (i) each producer was allocated a share of production based on ninety-five percent of the total estimated market demand; and (ii) any additional production allocations were to be made to all producers, in the same proportions as their original allocations, rather than by way of supplementary licences given only to those producers with unfilled orders (as under the initial scheme). ${ }^{36}$

The appellant, Central Canada Potash Co. Limited ("Central Canada"), had been incorporated by Noranda Mines Limited ("Noranda") and Central Farmers Fertilizer Company ("Central Farmers") which supplied large quantities of fertilizer to farmeroperated cooperative associations in the United States. In return for Noranda agreeing to develop a new potash mine, Central Farmers had agreed to purchase not less than one-half million tons of potash annually (with the right to increase its annual purchases to one and one-half million tons) for a period of twenty years commencing February 1970.

The effect of the "flat" prorationing scheme was to leave Central Canada unable to fulfil its contractual obligations to Central Farmers unless it obtained supplementary production licences. In 1972-73, Central Canada's prorationed allocation was short of the volumes it was obliged to sell to Central Farmers so it sought an increased allocation and, when its request was refused, brought mandamus proceedings to compel the issuance of a production quota that would enable it to meet is contractual commitment. Those proceedings were unsuccessful at first instance and subsequently before the Saskatchewan Court of Appeal and the Supreme Court of Canada. Central Canada then initiated proceedings to obtain a declaration that the prorationing scheme was invalid. Here it achieved better results, ultimately seeing a unanimous Supreme Court of Canada hold that the Regulations were ultra vires the Saskatchewan Legislature.

The following excerpt is taken from the reasons for decision delivered for the Court by Chief Justice Laskin:

\footnotetext{
It is, of course, true, that production controls and conservation measures with respect to natural resources in a Province are, ordinarily, matters within provincial legislative authority.... The situation may be different, however, where a province establishes a marketing scheme wish price fixing as its central feature. Indeed, it has been held that provincial legislative authority does not extend to the control or regulation of the marketing of provincial products, whether minerals or natural resources, in interprovincial or export rrade. The Saskatchewan Courts recognized this almost fifty years ago in the judgment in In re Grain Marketing Act. 1931. Legislation with this thrust in other Provinces has likewise been struck down: see Lawson v. Interior Tree Fruit \& Vegetable Committee of Direction, Re Sheep and Swine Marketing Scheme (P.E.I.).
}

The present case reduces itself therefore to a consideration of the true nature and character' of the prorationing and price stabilization schemes which are before us. This Coun cannot ignore the 
circumstances under which the Potash Conservation Regulations came into being, nor the market to which they were applied and in which they had their substantial operation. In Canadian Industrial Gas \& Oil Lid. v. Governmem of Saskatchewan, this Court, speaking in its majority judgment through Martland J.. said (at p. 568) that'provincial legislative authority does not extend to fixing the price to be charged or received in respect of the sale of goods in the export market'. It may properly be said here of potash as it was said there of oil that the legislation is directly aimed at the prodiuction of potash destined for export, and it has the effect of regulating the export price since the producer is effectively compelled to ohtain that price on the sale of his product' (at p. 569).

I do not agree with Chief Justice Culliton [who had given the judgment of the Saskatchewan Court of Appeal] that the consequence of invalidating the provincial scheme in this case is to move to the Parliament of Canada the power to control production of minerals in the Province and the price to be charged at the mine. There is no accretion at all to federal power in this case, which does not involve federal legislation, but simply a determination by this Court, in obedience to its duty, of a limitation on provincial legislative power. It is true, as he says that (with some exceptions, not relevant here) the British North America Act distributes all legislative power either to Parliament or to the provincial Legislatures, but it does not follow that legislation of a Province held to be invalid may ipso facto be validly enacted by Parliament in its very terms. It is nothing new for this Court, or indeed, for any Court in this country scized of a constitutional issuc, to go behind the words used by a Legislature and to sec what it is that it is doing. It is especially important for Courts, called upon to interpret and apply a constitution which limits legislative power, to do so in a case where not only the authorizing legislation but regulations enacted pursuant thereto are themselves couched in generalities, and the bite of a scheme envisaged by the parent legislation and the delegated regulations is found in administrative directions. ${ }^{37}$ [emphasis added]

In order to assess the constitutional validity of the Alberta legislation, it is necessary to analyze the market to which the NGMA, as amended, applies, as well as the circumstances in which the amendments have come into being. As previously indicated, the amending legislation purports to have broad application but the designation order makes the legislation presently apply only to A\&S. The legislation is therefore pointedly directed only at the California market for natural gas. The circumstances in which the amendments have been proposed also point to the conclusion that the legislation is "directly aimed" at natural gas in the international export market. The CPUC has been exerting a great deal of pressure on PG\&E to obtain lower gas prices, which in the view of the CPUC are being frustrated by the continued existence of the A\&S producer "pool." PG\&E is thus desirous of dismantling the "pool" in order to facilitate competition among producers for PG\&E volumes, which competition would, in the view of the CPUC, result in reduced gas prices to California consumers. Indications were that PG\&E gave direction to A\&S that the netback pricing agreement was not to be renewed, that certain Alberta natural gas producers reacted to the prospect of the demise of the netback agreement and hence the A\&S producer "pool" itself by seeking assistance from the Alberta Government, and that the amendment to the NGMA was the result. ${ }^{38}$ These circumstances suggest an attempt to control the sale of Alberta gas in the international market. 
If the principles established in CIGOL and Central Canada Potash are applied, a strong argument can be made that section 9.1 of the NGMA would be found by the Supreme Court of Canada to be ultra vires the Alberta legislature. The balance of Part 2 of the NGMA is in less jeopardy since those provisions are less obviously directed at international natural gas exports. ${ }^{39}$

\section{UNITED STATES CONSTITUTIONAL ISSUES}

By taking, and proposing to take, steps which will have an impact upon Canadian producers, and which may also frustrate or impede regulatory objectives of the FERC, the actions of the CPUC pose issues of federal preemption. Article VI, Clause 2 of the United States Constitution provides that the Constitution, and the "Laws of the United States which shall be made in Pursuance thereof" shall be "the Supreme Law of the Land .. . [any] Laws of any State to the Contrary notwithstanding." Thus, where federal and state law purport to govern the same area, the former prevails and the latter is deemed preempted. The FERC, in fact, has already held aspects of the CPUC proposed capacity allocation programs on the El Paso and Transwestern systems to be preempted. In $E l$ Paso Natural Gas Co., ${ }^{40}$ and in Transwestern Pipeline Co.," the FERC examined the CPUC's proposal to allocate interstate pipeline capacity on a "bundled" basis, ${ }^{42}$ meaning that capacity rights held by utilities on the interstate pipeline would be "bundled" with capacity on the intrastate local distribution systems, ${ }^{43}$ and the combined capacity mix would subsequently be "brokered" to customers. Under a "bundling" approach, however, jurisdiction over the implementation of capacity allocation becomes blurred, as the CPUC possesses jurisdiction over capacity rights on the intrastate portion of the pipeline and the

By virtue of subsection 92A(2) of the Constitution Act, 1867 the NGMA can affect interprovincial gas trade provided that it does not discriminate in price or supply. The "reading down" doctrine requires that, whenever possible, a statute is to be interpreted as being intra vires. Thus, a court might "read down" Part 2 of the NGMA so as to limit its application to interprovincial and not intemational exports. For a complete discussion of the "reading down" concept see Hogg, supra. note 23 at 327.

54 FERC para. 61,318 (1991) [hereinafter "El Paso"].

54 FERC para. 61,314 (1991) [hereinafter "Transwestern"].

In these two decisions, the FERC amended the pipelines blanket transportation certificates to authorize a transportation assignment program, pursuant to which holders of firm transportation capacity rights on the pipelines will be permitted to assign those rights to third parties.

For example, capacity on PGT, an interstate pipeline, would be "bundled" with that held on PG\&E, a "Hinshaw" pipeline. Section I(c) of the Natural Gas Act, otherwise known as the Hinshaw Amendment, provides as follows:

The [jurisdictional] provisions of this Act shall not apply to any person engaged in or legally authorized to engage in the transportation in interstate commerce ... of natural gas received by such person from another person within or at the boundary of a State if all the natural gas so received is ultimately consumed within such State, or to any facilities used by such person for such transportation ... provided that the rates and service of such person and facilities be subject to regulation by a State Commission.

Thus, PG\&E, as a Hinshaw pipeline, is a state-regulated entity transporting, or authorized to transport, natural gas in intrastite commerce, which gas is subsequently consumed entirely within the state of Califormia. 
FERC exercises jurisdiction over rights held on the interstate pipeline. Both El Paso and Transwestern clearly acknowledge the potential for conflict between federal and state objectives inherent in a "bundled" capacity allocation program, pursuant to which the CPUC and the FERC essentially exercise concurrent jurisdiction over capacity brokering. In fact, the "bundling" proposals in El Paso and Transwestern were found to be "inconsistent" with the exercise of federal jurisdiction over interstate capacity brokering and were deemed "unacceptable." capacity allocation procedure "would make it difficult, if not impossible, for the Commission to determine which component of the bundled rate is attributable to the interstate portion of the transaction" and to thereby regulate interstate rates effectively. ${ }^{45}$ Thus, since CPUC regulation of "bundled" intrastate and interstate capacity carried with it the potential to impact upon the rates charged for, and the allocation of, interstate capacity, thereby effectively bestowing upon the CPUC the power to veto decisions made by the FERC, such regulation was invalidated.

Similarly, CPUC action threatening the viability of Canadian gas purchase contracts may also be preempted by federal law. State regulation cannot stand to the extent that it actually conflicts with federal law or regulation. ${ }^{46}$ Such a conflict arises when "compliance with both federal and state regulations is a physical impossibility," or where state law "...stands as an obstacle to the accomplishment and execution of the full purposes and objectives of Congress. ${ }^{n+7}$

The issue thus becomes one of definition - when does action taken by a state commission constitute an "encroachment" upon the authority of the FERC sufficient to justify preempting the state action? In cases where preemption is not statutorily mandated, and where the activity sought to be regulated does not neatly fall within the scope of either state or federal regulation, the answer appears to depend upon the degree of conflict that would be posed by concurrent regulation of a natural gas company or utility and the extent to which the goals of the Natural Gas Act ("NGA") would be impeded by state regulation. For example, in Schneidewind the Michigan Public Service Commission ("MPSC") sought to regulate the activitics of natural gas companies by requiring those companies transporting natural gas in Michigan for public use to obtain MPSC approval before issuing long-term securities. ${ }^{+3}$ ANR Pipeline Company, an interstate pipeline whose activities are regulated by the FERC, objected, arguing that such state regulation is preempted by the NGA. The Supreme Court agreed, concluding that the MPSC was regulating "in a field [that] the NGA has occupied to the exclusion of state law. "49" In so holding, the Court noted that even though the FERC is not "expressly authorized" to regulate the issuance of securities by natural gas companies, preemption

El Paso Order at 29: Transwestern Order at 11.

Ibid.

See, e.g.. Schmeidewind v. ANR Pipeline Co., 108 S. C1. 1145, 1150 (1988) (hereinafter "Schmeidewind" |: Florida Lime \& Alocado Growers, Inc. v. Paul. 373 U.S. 132. 142-43 (1963) [hereinafter "Paul"]: Hines v. Davidowit=. 312 U.S. 52.67 (1941) |hereinafter "Hines"].

Paul, ibid. al 143: Hines, ibid. at 67.

Schmeidewind. supra, note 46 at 1149.

Ibid. at $\$ 151$. 
may be inferred from the degree of oversight the FERC is empowered to exercise over regulated entities such as ANR. ${ }^{50}$

Since a Congressional intent to regulate in this area could be gleaned from the provisions of the NGA, the attempt by MPSC to regulate issuance of securities by ANR constituted preempted regulation of the rates and facilities of the pipeline. The fact that the objectives underlying MPSC regulation mirrored those that had prompted federal regulation only served to bolster the conclusion of the Court that preemption was warranted. $^{51}$ As the "central purpose" of the state activity was to "regulate matters that Congress intended FERC to regulate," the MPSC efforts could not stand.

In addition, the Court found that preemption was mandated, irrespective of Congressional intent, because of the "imminent possibility of collision" between state and federal regulation. For example, if the MPSC were to refuse to grant a natural gas company the authority to issue a security for a FERC-approved project, the resulting disagreement between the two agencies could nullify the project and irreparably "interfere with the federal regulatory scheme." ${ }^{\text {52 }}$ Further, any state attempt to alter the capital structure of a FERC-regulated company would threaten to impinge upon federal ratemaking authority. ${ }^{53}$ Consequently, the spectre of conflict, standing by itself, was enough to preempt state regulation in Schneidewind.

Similarly, in Exxon Corp. v. Eagerton, the Court held that an Alabama statute, which prohibited natural gas producers from passing on increased oil and gas taxes to consumers, was preempted by the NGA. According to the Court, the state's pass-through prohibition impermissibly encroached upon the authority of the FERC to regulate prices of natural gas sold in interstate commerce. ${ }^{54}$ The Alabama law barred gas producers from increasing their prices to pass on a particular expense, tax increases, to their purchasers. As a result, the law "trespassed" upon the duty of FERC to determine just and reasonable rates by interfering with the allocation of costs associated with the sale of natural gas to consumers. ${ }^{\text {s5 }}$ Even though the producers were not FERC-regulated entities, state interference with the pricing of natural gas to flow in interstate commerce was sufficient to trigger application of the preemption doctrine.

In Northern Natural Gas Co. v. State Corp. Commission of Kansas, the Court invalidated orders of the Kansas Commission, which had required interstate pipeline companies to purchase natural gas ratably from all wells connecting with its pipeline

s1). Mid. at 1153 .

51. Such commonly-shared objectives were to protect investors, to ensure efficient service at reasonable rates, and to assure the proper maintenance of facilities and continuation of service. Ibid. at 1154 .

52. Ibid. at 1156.

53. Ibid.

s. $\quad 462$ U.S. $176(1983)$ at $184-85$.

ss. $\quad$ hid. at 185 . 
system in each gas field. ${ }^{56}$ The Court stated that the NGA "precludes not merely direct regulation by the States" of natural gas prices, but also "state regulation which would indirectly achieve the same result.".57 Because the Kansas Commission's orders necessarily affected the ability of the Federal Power Commission ("FPC") to "comprehensively and effectively" regulate the sale and transportation of natural gas, and because such orders impeded the NGA goal of effectuating uniformity of regulation, the orders impermissibly "invade[d] the federal agency's exclusive domain. ${ }^{158}$ As noted by the Court, the readjustment of purchasing patterns potentially engendered by state regulation could "seriously impair the [FPC] authority to regulate the intricate relationship between the purchasers' cost structures and . . . costs to . . . customers," a matter over which the FPC has "paramount and exclusive authority." ${ }^{\text {(59 }}$ Of no relevance to the Court was the Kansas contention that ratable taking was essential for conservation purposes, and that conservation concerns fell within the state regulatory ambit. Rather, the Court found that otherwise-legitimate conservation measures directed toward interstate pipeline purchases could not be sustained when they threatened the "achievement of the comprehensive scheme of federal regulation."

The Northern Natural holding was reaffirmed in Transcontinental Gas Pipe Line Corp. v. State Oil and Gas Bd. of Mississippi, ${ }^{61}$ where the Court struck down on preemption grounds a virtually identical state regulation despite the intervening enactment of the Natural Gas Policy Act ("NGPA").62 Mississippi posited that the NGPA had effectively nullified the holding of Northern Natural by vesting in the states regulatory power over the sale of gas at the wellhead, thereby altering those characteristics of the federal regulatory scheme which the Northern Natural Court had found determinative. The Transcontinental Court, however, rejected the attempt by the state to narrow the scope of federal regulation. The Court noted that while the NGPA encouraged a shift from price regulation by the FERC to price regulation by the market, such a shift was not intended to also sanction price regulation by the states, that is, it was not foreseen that the states would step in and substitute for the FERC in the area of natural gas pricing. Rather, pricing practices still remained a "subject of deep federal concern." ${ }^{\text {.63 }}$ Further, implementation of the Mississippi order would upset the "uniformity of the federal

372 U.S. 84 (1963) [hereinafter "Northern Natural"]. A Kansas statute empowered the Commission to "...regulate the taking of natural gas from any and all ... common sources of supply within [the] state as to prevent the inequitable or unfair taking from such common source of supply ... and to prevent unreasonable discrimination ... in favor of or against any producer in any such common source of supply." It was pursuant to this statute that the Kansas Commission sought to require Northern Natural to increase its takes from producers' wells with whom it did not have a contractual arrangement.

57.

$5 \times$.

54.

lhid. at 90.

Ibid. at 91-92.

Ibid. at 92.

libid. at 94.

474 U.S. 409 (1986) |hereinafter "Transcomtinental"]. The Mississippi regulation required Transco. an interstate pipeline, to purchase gas from all parties owning interests in a common gas pool. Such gas had been classified as "high cost" gas under section 107(c)(1) of the Natural Gas Policy Act of 1978 (NGPA), 15 U.S.C. $\$ 3317$ (c)(1). 474 U.S. al 411.

15 U.S.C. $\$ 3301$ et seq (1988).

Transcontinental, supra, note 61 at 422. 
scheme," as pipelines would thereby face the prospect of having to comply with differing state regulations. ${ }^{64}$ Finally, the state regulation at issue threatened to distort the market by forcing upon pipelines purchasing decisions. ${ }^{65}$ Thus, since the state regulation posed an obstacle to the smooth functioning of federal natural gas regulation, and since the underlying concerns and objectives of FERC had not been altered by passage of the NGPA, the Mississippi regulation was held preempted.

In Nantahala Power \& Light Co. v. Thornburg, ${ }^{66}$ the Court preempted state regulation of a utility's electricity rates. The North Carolina Utilities Commission ("NCUC"), which was responsible for regulating the rates of Nantahala's retail sales in North Carolina, determined that Nantahala received a certain percentage of low-cost power from the Tennessee Valley Authority. The FERC, however, had arrived at a lower percentage. As a result, the NCUC decided that the FERC had underestimated the amount of low-cost power available to Nantahala, and ordered Nantahala to reduce its retail rates to reflect the NCUC allocation of low-cost electricity. ${ }^{67}$ The Supreme Court invalidated the NCUC action, finding that once the FERC sets wholesale rates to be charged to interstate customers, a state may not conclude in setting retail rates that the FERC-approved wholesale rates are unreasonable. ${ }^{68}$ Thus, even though the NCUC activity involved the setting of intrastate retail rates, an activity properly within the sphere of a state agency, the NCUC order ran directly counter to a result reached by the FERC and thereby "impermissibly interfere[d] with the scheme of federal regulation." ${ }^{69}$ A similar relevant case, Narragansett Electric Company v. Burke, ${ }^{70}$ held that the Rhode Island Public Utilities Commission lacked the authority to inquire into the reasonableness of an interstate electricity supplier's wholesale rate because state commissions are preempted from scrutinizing interstate prices.

In Public Service Commission of West Virginia v. FPC ${ }^{71}$ the issue presented to the Court was whether the FPC, in exercising its jurisdiction over the abandonment and subsequent acquisition of a pipeline, was required to condition its approval upon concurrent approval by the West Virginia regulatory commission. The pipeline had been certificated by the FPC for use in interstate commerce, but at the time approval was sought, some interstate customers were being served by the pipeline's facilities. The court held that the regulatory authority of the state commission had been "superseded" by the jurisdiction of the FPC over interstate pipelines, and noted that having to obtain additional local commission approval would only engender "confusion." ${ }^{\text {"72 }}$ As the court stated, "[i]f the acquisition of rights in an interstate transportation line were subject to the veto of every state regulatory agency along the line, a single agency could seriously impair

Ihid. at 962.

Ibid. al 968-970.

lbid. al 972.

381 A.2d I358 (R.I. 1978) 1362-63.

437 F.2d 1234 (4th Cir. 1971).

lhid. at 1239. 
interstate commerce and the interests protected by the [Natural Gas] Act and prevent [the] FPC from performing its statutory duties." ${ }^{73}$

While the CPUC has a legitimate interest in the allocation of intrastate capacity and in the promotion of competition in the California market, United States courts have generally rejected the notion that state interests should be balanced against federal interests in a preemption analysis or that the strength of the state interest should be a relevant concern. What has been deemed relevant by the courts is the threat posed by a state regulatory commission acting in a manner that would disrupt national policy. "Bundling" of interstate and intrastate capacity has already been found to thwart federal regulatory objectives and to unduly interfere with FERC jurisdiction over the operation of interstate pipelines bringing gas to California. ${ }^{74}$ Similarly, where CPUC action may threaten the viability of international gas contracts, federal interests are clearly implicated. The FERC is presently seeking to balance the interests of Canadian and domestic producers and any action by the CPUC which may be interpreted as upsetting that balance is therefore likely to be preempted.

\section{CANADIAN COMPETITION LAW CONSIDERATIONS}

The process for restructuring contracts also raises competition issues. From the Canadian perspective, the question is whether the members of a producer "pool" face either criminal sanction or civil liability under the Competition Act $^{75}$ if they pursue a course of conduct, individually or collectively, which is required or authorized under the NGMA, the NGMR, or the Commission Directive of the APMC.

Economists have for some time considered regulation and competition as representing alternative means of controlling private economic power and promoting economic activity and the efficient use of scarce resources. This theory is sometimes offered as the rationale underlying what has come to be known as the regulated conduct defence to competition law liability. ${ }^{76}$

Reference Re the Farm Products Marketing Act ${ }^{77}$ is the seminal decision respecting this issue. In that case, the Supreme Court of Canada considered whether the activities of the Ontario Farm Products Marketing Board, which included controlling the prices of

Ibid. Sce also Public Serv. Comm'n of Kentucky v. FERC, 610 F.2d 439 (6th Cir. 1979) (court holding that FERC, rather than Kentucky PSC, jurisdiction was appropriate over the initial flow of natural gas from wellheads and gathering lines to compressor stations: in so holding, court notes that in "borderline ljurisdictional] cases . . . courts [must] ask whether it is within the capability of states to regulate in accordance with the purpose of the Natural Gas Act;" in this case, regulation by Kentucky would have utterly thwarted the goal of a fair "nationwide allocation of natural gas supplies.").

See El Paso, supra, note 40 and Transwestern, supra, note 41.

R.S.C. 1985, c. C-34.

See for example, G. Kaiser, "Competition Law and the Regulated Sector" in J.R.S. Prichard, W.T. Stanbury and T.A. Wilson, eds., Canadian Competition Policy: Essays in Law and Economics (Toronto: Butterworth \& Co. (Canada) Lid., 1979) 347 at 347-348.

[1957] S.C.R. 198 [hereinafter "Farm Products"]. 
certain agricultural products, contravened the Combines Investigation Act $^{78}$ and the Criminal Code. While the principal attack on the legislation establishing the Marketing Board was based upon the constitutional division of powers and the contention that the provincial legislation infringed upon the federal power to regulate trade and commerce, it was also argued that the legislation conflicted with parts of the Combines Investigation Act, 1952. The Court delivered six separate sets of reasons, but the most relevant passage appears in the judgment of Mr. Justice Locke:

In my opinion, neither the provisions of the Combines Imvestigation Act . . . nor of ... the Criminal Code ... are objections to the schemes in question to the extent that they are within the power which may be validly granted by the Legislature under the terms of the British North America Act. It cannot be said, in my opinion, that within the terms of para. (a)(vi) of s. 2 of the Combines Investigation Act the scheme'is likely to operate to the detriment or against the interests of the public, whether consumers, producers or others'. Rather is it a scheme the carrying out of which is deemed to be in the public interest. Furthermore, the offence defined by $s$. 2 which renders a person subject to the penalties prescribed by $s .32$ is a crime against the state. I think that to perform an act which the Legislature is empowered to and has authorized cannot be an offence against the statc.

The same reasoning applies, in my opinion, to s. 411 of the Criminal Code. I consider that the section has no application to a scheme authorized by a Legislature under its powers conferred by the same statute which, by s. 91, gave to Parliament the power to pass laws in relation to the criminal law. If, indeed, the section could be construed as applying to such an act, I think it would be impossible to say that a scheme deemed by the Legislature to be in the public interest could be held to unduly limit or prevent competition within the meaning of the section. ${ }^{7 "}$

In another classic decision, $R$. v. Canadian Breweries Limited ${ }^{\text {*0 }}$, the accused was charged under the Combines Investigation Act, 1952 with operating as a "merger" which constituted a prohibited "combine." The essence of the allegation was that, by acquiring twenty-three brewing firms, Canadian Breweries Limited had violated both the merger and conspiracy provisions of the Combines Imvestigation Act, 1952. The theory of the defence was that the merger did not prevent or lessen competition unduly having regard to the restriction on competition validly imposed by government authorities, and also having regard to the vigorous competition which the company faced from its powerful and experienced competitors in those aspects of the business that were unrestricted (such as quality, taste and packaging). The Ontario High Court considered that the object of the Combines Investigation Act, 1952 was "to protect the public interest against the enhancement of prices that will likely flow from combines as defined in the Act." However, the Court recognized that the price of beer was fixed by the Ontario Liquor Board under authority of the Liquor Control Act ${ }^{82}$ with the result that the accused could not be responsible for creating the mischief against which the Combines Investigation Act, 1952 was directed. Chief Justice McRuer wrote on behalf of the Court:

R.S.C. 1952, c. 314 [hereinafter Combines Investigation Act. 1952].

Farm Products, supra, note 77 at 239.

[1960] O.R. 601 [hereinafter "Canadian Breweries"].

lbid. at 629.

R.S.O. 1950, c. 210. 
When a provincial legislature has conferred on a commission or board the power to regulate an industry and fix prices, and the power has been exercised, the Court must assume that the power is exercised in the public interest. In such cases, in order to succeed in a prosecution laid under the Act with respect to the operation of a combine. I think it must be shown that the combine has operated, or is likely to operate, so as to hinder or prevent the provincial body from effectively exercising the powers given to it to protect the public interest. ${ }^{\mathrm{x}}$

The regulated conduct defence has been the subject of considerable controversy for some time and there have been attempts to restrict its compass by statute. Various abandoned drafts of the Competition Act included amendments directed to that purpose. For example Bill C-13, introduced in Parliament in 1977, contemplated intervention by the proposed Competition Policy Advocate before regulatory agencies and boards and a right of appeal where the Advocate was dissatisfied with the decision rendered after his intervention. It was intended that the decisions of the agencies and boards would be subject to review on the grounds that they did not exercise their powers in a manner least restrictive of competition. None of the proposals were carried forward in the Competition Act as it was enacted.

The decision of the Supreme Court of Canada in A.G. Canada v. Law Society of British Columbia; Jabour v. Law Society of British Columbia ${ }^{84}$ is well known to most Canadian lawyers primarily since it concerned the issue of whether, or in what way, lawyers may advertise their services to the public. In fact, that issue was not the focus of the litigation. What is more significant is that, in general terms, the Supreme Court of Canada applied the regulated conduct defence in holding that the ruling body of a self-governing profession, functioning under a constitutionally valid provincial statute, was not subject to the criminal provisions of the Combines Investigation Act. ${ }^{85}$

The regulated conduct defence was considered in a comparatively recent decision rendered by Madam Justice Reed of the Federal Court Trial Division in Industrial Milk Producers Association v. Milk Board. ${ }^{86}$ The Industrial Milk Producers case concerned a civil action brought under the Competition Act. The plaintiffs alleged that they had suffered damages as a result of a conspiracy or agreement to prevent or unduly lessen competition in the industrial milk market. They had been refused an "industrial milk production quota" by the British Columbia Milk Board (the "B.C. Milk Board") and therefore were prohibited from marketing industrial milk. Industrial milk production quotas were only issued to those dairy farmers who already held "fluid milk quotas." The plaintiffs claimed that this left them in the position of having to purchase fluid milk quotas at exorbitant prices.

The B.C. Milk Board was afforded authority, pursuant to the Milk Industry Act of British Columbia ${ }^{87}$, to regulate the production and marketing of milk in interprovincial

Canadian Breweries, supra, note 80 at 629.

[1982] 2 S.C.R. 307.

R.S.C. 1970 , c. C-23.

(1988), 47 D.L.R. (4th) 710 [hereinafter "Industrial Milk Producers"].

R.S.B.C. 1979 , c. 258. 
trade. The federal Agricultural Products Marketing Act ${ }^{88}$ also delegated authority to the B.C. Milk Board to regulate milk produced for the interprovincial and export markets.

The plaintiffs complained that the B.C. Milk Board had implemented a production and marketing scheme designed to eliminate all competition in the dairy industry and to enhance and fix prices for the benefit of existing quota holders. The scheme was said to operate to the detriment of not only dairy farmers wishing to compete with other farmers already holding fluid milk quotas but of consumers as well.

The B.C. Milk Board applied to have the statement of claim struck out as disclosing no reasonable cause of action. While they did not contest the issue of whether or not their activities contravened the Competition Act, they argued that, even if that were the case, their activities were expressly authorized by federal and provincial legislation and therefore were exempt from prosecution or liability pursuant to the Competition Act. Madam Justice Reed accepted those arguments and struck out the statement of claim. After an extensive consideration of the jurisprudence establishing the regulated conduct defence, she concluded that the defence was available to the defendants notwithstanding that they were defending a civil action rather than a criminal prosecution.

Most importantly, Reed J. found no merit in the argument founded on Canadian Breweries that if one aspect of an industry, such as prices, is regulated, then there is no longer a free market and consequently no room for application of competition law to other aspects of the industry:

I accept counsel for the plaintiffs' argument that it is a regulated industry defence, not an exemption, which is pertinent. Indeed, as I read the cases it is a regulated conduct defence. It is not accurate merely to identify an industry as one which is regulated by federal or provincial legislation and then conclude that all activities carried on by individuals in that industry are exempt from the Competition Act. It is not the various industries as a whole which are exempt from the application of the Competition Act but merely activities which are required or authorized by the federal or provincial legislation as the case may be. ${ }^{\text {.9 }}$

It is safest then to conclude that regulation of some aspect or aspects of an industry in which one operates will not answer a civil action or a criminal prosecution under the Competition Act unless the impugned activities themselves are required or authorized by legislation. ${ }^{90}$

R.S.C. 1970 , c. A-7.

Industrial Milk Producers, supra, note 86 at 726.

The suggestion that a court might declare the NGMA or section 9.1 to be ultra vires the Alberta legislature gives rise to the rather intriguing question of what effect such a decision might have on the availability of the regulated conduct defence. In most of the cases where the defence has been accepted, the courts have at least mentioned, if not emphasized, that the anti-competitive conduct was required or authorized by a valid statute. It might be successfully argued by analogy to the defence known in criminal law as "obedience to the de facto authority." that the statute should protect the anti-competitive conduct until it is declared ultra vires. For a discussion of the defence of obedience to the de facto authority see A.W. Mewett and M. Manning, Criminal Law, 2nd ed. (Toronto: Butterworth \& Co. (Canada) Lid., 1985) at 373-376. 
The actions or activities which are required or authorized by the NGMA were described earlier. Essentially, a shipper of "netback gas" is precluded from removing gas from Alberta for resale outside Alberta unless the APMC has made a finding of producer support, meaning that it has determined that the shipper has, through the procedures prescribed in the regulations, obtained the minimum prescribed degree of support from producers. While the concept in the NGMA of the establishment of a common price or a common pricing mechanism for all "netback gas" may well offend against the Competition Act, the gas producers can rely upon the regulated conduct defence to avoid criminal or civil liability. There is, however, no provision in the NGMA or the NGMR to require or authorize a commitment by a shipper to purchase a specified portion of its total purchases from a particular producer, and no regulated conduct defence would be available if such an agreement existed and was contrary to the Competition Act. The significance of this fact for members of the producer "pool" is that a producer who is excluded from those agreements may have grounds to complain that such contracts offend against the Competition Act. ${ }^{91}$ Similarly, there might be grounds for Competition Act liability if the producers were to consult with one another during the balloting process. ${ }^{92}$ Since such consultation is not required or authorized by statute, no regulated conduct defence would apply.

On July 18, 1991, section 14.2 of the NGMR was promulgated pursuant to sections 9.1 and 25 of the NGMA. Section 14.2 establishes a mechanism under which a "designated shipper" and/or one or more of its "netback producers" may petition the Alberta Minister of Energy with a request that a vote of the netback producers be conducted concerning the question of whether the application of section 9.1 of the NGMA to the shipper and the netback pricing agreements to which the shipper is a party should be terminated. The petition process is initiated by the filing with the APMC of a notice of intention to petition the Minister. Upon receiving such a notice, the APMC is required to issue a directive to the designated shipper stating that it has received the notice and directing that the designated shipper convene a meeting with its netback producers for the purpose of initiating a negotiating process between the shipper and the netback producers and among the netback producers in respect to matters pertaining to the proposed petition. ${ }^{93}$ This sort of negotiation process might well give rise to concerns, on the part of both shippers and producers, regarding Competition Act liability, although direction of the negotiation

For example. it is at least arguable that this sort of agreement would contravene paragraph $45(1)(a)$ of the Competition Act if it limited unduly access to the pipelines which transmit gas to California. Further, such agreements might offend against paragraph $45(1)(c)$ as unduly lessening competition in the transportation or supply of natural gas or against paragraph $45(1)(d)$ as unduly restraining or injuring competition in some other way. It is also important to recognize that the so-called "export exemption" which arises under subsection 45(5) of the Competition Act may not be available since the offending agreements may well have the effect of restricting competing producers from entering into the gas expon business (see paragraph $45(6)(b)$ ) or lessening competition in the supply of pipeline capacity (see paragraph 45(6)(c)).

32. It could be argued that such communications would constitute a conspiracy to enhance unreasonably the price of natural gas contrary to paragraph $45(1)(b)$ of the Competition Act.

43. On September 23, 1991, the APMC issued a directive to A\&S advising that it had received two notices of intention to petition the Minister of Energy. The first notice was filed with the APMC on July 30, 1991 by Anderson Exploration Lid. The second was filed by A\&S itself on August 7, 1991. The APMC issued a Commission Directive on September 23. 1991. 
process by regulation raises an argument for the application of the regulated conduct defence. $^{94}$

\section{UNITED STATES ANTITRUST CONSIDERATIONS}

The supply "pool" arrangement permitted under the NGMA also raises issues under United States antitrust law - whether such an arrangement violates section 1 of the Sherman Act. Since aggregators operating under netback pricing agreements do not negotiate prices with individual producers but propose a uniform price for the approval of all prociucers in the pool, it could be argued that aggregators and producers have entered into an agreement to restrain trade by fixing the price of natural gas at the wellhead. Private parties that are harmed by antitrust violations can recover treble damages and legal fees from the defendants. ${ }^{95}$

A United States court probably would exercise jurisdiction over an alleged conspiracy between Canadian producers and shippers to fix or affeci gas prices. The leading case on the extraterritorial application of United States antitrust law is United States v. Aluminum Co. of America in which Judge Learned Hand ruled that the United States antitrust laws could be applied to prohibit agreements in restraint of trade even where the parties to the conspiracy were all foreign and the agreements were made and carried out outside the United States "if they were intended to affect imports and did affect them." ${ }^{\text {"97 }}$ The "effects test" announced in Alcoa continues to represent the rule for the extraterritorial application of U.S. antitrust law. ${ }^{98}$ A United States court would likely conclude that an alleged conspiracy among Canadian producers of natural gas to fix the wellhead price of gas exported to the United States was intended to and did have a direct, substantial, and foreseeable effect on United States commerce.

Canadian gas producers and shippers who export gas to the United States would probably also be found subject to the in personam jurisdiction of a United States court. Under the due process clause of the United States Constitution, United States courts cannot exercise jurisdiction over a foreign defendant unless the defendant has "minimum contacts" with the forum such that the exercise of jurisdiction "does not offend "traditional

Neither section 14.2 nor the Commission Directive contemplate the imposition of any sanction against either designated shippers or netback producers that do not pursue negotiations as contemplated. This fact makes the application of the regulated conduct defence somewhat less obvious than it might otherwise be.

45. 15 U.S.C. $\$ 15(a)$ (1988).

\%. 148 F.2d 416 (2d Cir. 1945) [hereinafter "Alcoa"|.

97. Ibid. at 444 .

4*. See for example, Forcign Trade Antitrust Improvements Act of 1982, 15 U.S.C. \$ 6 a (1988) (exempts joint export activity from the Sherman Act unless such conduct has a "direct, substantial and reasonably foreseeable effect" on U.S. commerce); United States Department of Justice. Antitrust Division. Antitrust Enforcement Guidelines for International Operations, \& 5 (1988) (no subject matter jurisdiction over antitrust violation abroad unless such conduct has a "direct, substantial and reasonably foreseeable effect" on U.S. Commerce). 
notions of fair play and substantial justice'."99 In an antitrust suit against Canadian participants in a supply pool, the personal jurisdiction issue would turn on a factual inquiry into contacts of the aggregator and the producers with the United States.

It is reasonable to assume that a United States court would exercise personal jurisdiction over not only the aggregator but also the producers participating in any price pool set up to export gas to the United States. Although the aggregator may be a Canadian corporation that does not operate in the United States, if the purpose of its existence and the purpose of each individual supply contract with each individual producer is to export Canadian gas to the United States, a court could easily conclude that the aggregator and the producers have purposefully availed themselves of the United States market and subjected themselves personally to the jurisdiction of the court.

Assuming United States jurisdiction would be present, the question remains whether the netback arrangement violates United States antitrust laws. Section 1 of the Sherman Act states that "[e]very contract, combination in the form of trust or otherwise, or conspiracy in restraint of trade or commerce among the several states, or with foreign nations is declared to be illegal." $1(x)$ In order to prevail on a Sherman Act section 1 claim, a plaintiff must establish: (1) a contract, combination or conspiracy; (2) that is an unreasonable restraint of trade; and (3) that the restraint is in or affects interstate or foreign commerce.

It could be argued that the requirement of a finding of majority support for netback pricing under the NGMA facilitates collusion on pricing among producers in a supply pool. Under the Sherman Act, a conspiracy need not arise from an express agreement, and its existence can be inferred from circumstantial evidence. Evidence of parallel behaviour standing alone, however, does not necessarily support an inference of conspiracy. ${ }^{101}$

Imternational Shoe Co. v. Washington, 326 U.S. 310,316 (1945) (quoting Milliken v. Meyer, 311 U.S. 457, 463 (1940)). See for example, Asahi Metal Industry Co. v. Superior Court of California. 480 U.S. 102, 116 (1987) (California state court could not exercise personal jurisdiction over Japanese manufacturer of tire valve assemblies in products liability action unless the defendant had "purposefully avail|ed] itself of the California markel"); Go-Video. Inc. v. Akai Electric Co., 885 F.2d 1406, 1413 (9h Cir. 1989) (personal jurisdiction for an antitrust suit against an alien corporation could be obtained in any judicial district in the United States, provided the defendant has sufficient minimum contacts with the United States).

100. 15 U.S.C. $\$ 1(1988)$.

101. Theatre Enter., Inc. v. Paramount Film Distrib. Corp., 346 U.S. 537, 541 (1954) ("Circumstantial evidence of consciously parallel behaviour may have made heavy inroads into the traditional judicial attitude toward conspiracy: but 'conscious parallelism' has not yet read conspiracy out of the Sherman Act entirely."); Barry v. Blue Cross of Cal.. 805 F.2d 866 (9th Cir. 1986) (the fact that several thousand physicians signed identical contracts to provide services to insurance plan members at predetermined prices does not support an inference of conspiracy without additional evidence that the physicians' actions were interdependent); Supermarket of Homes v. San Fernando Valley Bd. of Realtors, 786 F.2d 1400. 1405 (9th Cir. 1986) (parallel pricing alone does not prove conspiracy to fix prices). 
A number of factors need to be considered in determining whether an unlawful agreement can be inferred from circumstantial evidence. ${ }^{102}$ "Such factors may include price parallelism, product uniformity, exchange of price information, and opportunity to meet to form anticompetitive policies." 10.3 In addition, a plaintiff must show that by engaging in the parallel conduct, each alleged conspirator was acting against its own selfinterest, ${ }^{104}$ that is, evidence must be adduced that tends to exclude the possibility that the alleged conspirators acted independently. If the conduct of the defendant is consistent both with permissible competition and with illegal conspiracy, then evidence of such conduct without more does not support an inference of antitrust conspiracy. ${ }^{105}$

A supply pool operating under the NGMA involves a series of contracts between individual producers and the aggregator under which each producer votes to accept a price that applies to all producers. The Court of Appeals has held that a similar arrangement involving individual health care providers under contracts with a common health maintenance organization did not violate the Sherman Act. In Barry v. Blue Cross of California, ${ }^{106}$ two doctors complained that a prepaid health care plan offered by Blue Cross violated section 1 of the Sherman Act as a horizontal agreement among participating physicians to fix prices. Participating physicians signed identical contracts agreeing to provide specific medical services to insureds under a uniform fee schedule proposed by Blue Cross. The court granted summary judgment for the defendants, holding that there was no proof that the participating doctors controlled or agreed upon the plan fee schedule and that an inference of conspiracy could not be supported solely by evidence of conscious parallelism. ${ }^{117}$ The court found that joining the plan was not contrary to a physician's independent interest and that, in fact, independent business reasons supported joining. ${ }^{108}$

This opinion suggests that a netback pricing agreement, under which a series of suppliers individually enter into agreements with a marketer to supply natural gas at a uniform price would not, as a matter of law, constitute a horizontal agreement to fix prices absent some degree of coordinated control of prices by the suppliers.

A more recent decision, however, has held that conscious parallelism, standing alone, may support an inference of price fixing. In re Coordinated Pretrial Proceedings in Petroleum Products Antitrust Litigation ${ }^{109}$ the plaintiffs attempted to prove an alleged section 1 price-fixing conspiracy among major oil companies by showing a pattern of parallel conduct in the wholesale gasoline market in the western United States. The Court of Appeals reversed the district court grant of summary judgment for defendants and adopted a new standard of review. The court suggested that the law does not prohibit an

\footnotetext{
102. Wilcox v. First Imterstate Bank of Oregon, N.A., 815 F.2d 522 (9th Cir. 1987).

103. Ibid. at 525-526.

Ios. Ihid. at 527.

105. Matsushita Electric Industrial Co. v. Zenith Radio Corp., 475 U.S. 574 (1986): Monsanto Co. v. Spray-Rite Serv. Corp., 465 U.S. 752.764 (1984).

11*. $\quad 805$ F.2d 866 (91h Cir. 1986).

167. Thid. at 868-869.

10s. Ibid. at 870 .

109. 906 F.2d 432 (9th Cir. 1990) [hereinafter "Petroleum Products Amtirust Litigation"].
} 
inference of conspiracy on the basis of circumstantial evidence of parallel conduct merely because the parallel behaviour is equally consistent with lawful, independent conduct. If it would be equally reasonable to conclude that the parallel behaviour is the product of an unlawful conspiracy, the fact finder should be permitted to draw such an inference, unless permitting such an inference "would pose a significant deterrent to beneficial procompetitive behaviour." 10 While the impact and correctness of this holding is not entirely clear, it will probably make it more difficult for defendants to obtain summary judgment in price-fixing cases.

Whether a United States court would find participants in a supply pool liable for an antitrust violation would depend on the facts proven at trial. Although the price at which producers in a pool sell the gas to an aggregator is uniform, this uniformity could result as easily from the bidding process as from any agreement among competing producers. Nevertheless, the Petroleum Products Antitrust Litigation holding suggests that evidence of uniform pricing and similar contracts could be enough to survive a motion for summary judgment. Moreover, a plaintiff could argue that submitting proposed prices for majority approval indicates a degree of control and interdependence among producers that was not present among the participating physicians in Barry v. Blue Cross. If the court did not grant an early motion for summary judgment, the ultimate resolution of this issue would hinge on whether the plaintiff could produce evidence of producer communication and collaboration regarding prices.

The second element of a Sherman Act claim is that the agreement must unreasonably restrict competition. In making this determination, courts have employed two methods of analysis: the per se rule and the rule of reason. The Supreme Court explained the difference between the two standards:

In the first category are agreements whose nature and necessary effect are so plainly anticompetitive that no elaborate study of the industry is needed to establish their illegality - they are 'illegal per se.' In the second category are agreements whose competitive effect can only be evaluated by the facts peculiar to the business, the history of the restrain, and the reasons why it was imposed."'

As a general rule, agreements to fix prices or restrict output are illegal per $s e e^{112}$ although the Supreme Court has found exceptions to this rule. In Broadcast Music, Inc. v. Columbia Broadcasting System, Inc., ${ }^{13}$ the court applied a rule of reason analysis to an agreement among composers and publishers to market copyrighted musical works at fixed prices under a blanket licence. Similarly, in National Collegiate Athletic Association v. Board of Regents of the University of Oklahoma, ${ }^{1 / 4}$ the court considered an agreement

Ihid. at 437-440.

National Soc'y of Professional Engr's v. United States, 435 U.S. 679. 692 (1978).

Arizona v. Maricopa County Medical Soc'y. 457 U.S. 332, 356-57 (1982) (horizontal price fixing illegal per se); 324 Liquor Corp. v. Duffy, 107 S. Ct. 720, 724-5 (1987) (vertical price fixing illegal per se).

441 U.S. 1 (1979).

468 U.S. 85 (1984). 
among colleges and universities to fix the price of broadcast rights to televised football games under the rule of reason.

There is no bright line separating the two modes of analysis. Nevertheless, given the unusual set of circumstances in which the price pool arrangements arose, and the manner in which overlapping regulatory schemes of state, provincial and national governments impinge on the natural operation of gas markets, it is more likely that a court would decide that the pricing mechanism should be analyzed under the rule of reason rather than the illegal per se rule. ${ }^{115}$

Under a rule of reason analysis, the court must examine the degree to which the alleged restraint restricts commerce and weigh its anticompetitive and procompetitive features to determine whether the arrangement is, on balance, anticompetitive. This inquiry can be detailed and complicated. Its result - and whether per se illegality applies - will depend in part on the nature of the agreement, if any, proved by the plaintiff. If the plaintiff proves that competing producers agreed on the prices for which they would vote under the price pool, without authorization under Canadian law, the court could find the agreement illegal per se. If, on the other hand, the plaintiff proves nothing more than a series of unilateral, independent producer responses to the aggregator's bids, a United States court is unlikely to find an illegal agreement even under the rule of reason.

The third requirement of a Sherman Act violation is that the agreement must have some effect on United States commerce. It is well established that intrastate activities that have an adverse effect on interstate commerce are within the scope of the Sherman Act. ${ }^{116}$ In the case of foreign conduct, an agreement that has a direct, substantial, and reasonably foreseeable effect on United States commerce for purposes of subject matter jurisdiction should satisfy the "affecting commerce" element of a section 1 violation of the Sherman Act. Thus, if a court determines that it has subject matter jurisdiction over the price pool arrangement, then the price pool has a sufficient effect on United States commerce to meet the third requirement of a section 1 violation.

Two threshold defences that are relevant in this analysis are the Act of State doctrine and its corollary, Foreign Sovereign Compulsion. The Act of State doctrine "precludes the courts of [the United States] from inquiring into the validity of the public acts of a

A federal court in New Mexico has ruled that the per se doctrine would not be applied to an alleged conspiracy among producers and suppliers to fix wellhead gas prices on a motion for summary judgment. In re New Mexico Natural Gas Antitust Litigation, 1982-1 Trade Cas. para. 64,685 (D.N.M. 1982) ("The business conduct challenged here has not yet been fully analyzed by the courts in the context of the competitive conditions present in the natural gas industry so as to warrant automatic application of a per se rulc of illegality."). The court left open the question of per se liability, however, pending a full development of the facts at trial. Ihid. at 73,718-73,719. But see Illinois ex rel Harrigan v. Panhandle E. Pipe Line Co., 730 F. Supp. 826 (C.D. Ill. 1990) (alleged tying of sale of gas to sale of transmission services did not violate section I under a rule of reason analysis).

116. See for example, Hospital Building Co. v. Trustees of Rex Hosp., 425 U.S. 738, 743 (1976) (Commerce element satisfied if activity "substantially and adversely affects interstate commerce"). 
recognized foreign sovereign power committed within its own territory." 117 The Act of State doctrine does not, however, bar inquiries into the validity of acts of a state in a purely commercial context. ${ }^{118}$ Moreover, the mere fact that an act of state is involved will not shield private conduct from scrutiny if the validity of the sovereign act is not at issue. $^{119}$

The Act of State doctrine probably would not preclude an inquiry into the legality of the current price pool system under United States antitrust law because there is no act of state directly at issue. Neither the NEB nor the Alberta government sets the wellhead price or the export price, but both prices are determined among private parties.

Under the related doctrine of Foreign Sovereign Compulsion, otherwise illegal conduct by private parties may be immune from antitrust scrutiny if the offending conduct is compelled by a foreign government. ${ }^{120}$ The defence of Foreign Sovereign Compulsion would not apply unless the province of Alberta compels rather than merely condones the collective negotiation of prices for natural gas at the wellhead. Although Alberta prohibits an aggregator from removing gas from the province under a producer pool arrangement unless the prescribed minimum degree of support for the price has been obtained from producers, aggregators have been permitted to negotiate prices individually with producers in lieu of maintaining the price pool system. If maintenance of the price pool is merely authorized and not required, the defence of Foreign Sovereign Compulsion would not preclude an examination of the pricing system under United States antitrust laws.

Although the "state action" doctrine of Parker v. Brow'n"12 is roughly analogous to the Act of State and Foreign Sovereign Compulsion doctrines, it probably would not exempt private action merely condoned but not compelled by a foreign government. The state action doctrine immunizes from antitrust liability the sovereign actions of a state of the United States as well as private actions that are clearly authorized and actively supervised by the state. ${ }^{122}$ The state action doctrine recognizes the rights of states under the United States federal system to regulate intrastate commerce. It is not clear that the

Banco Nacional de Cuba v. Sabbatino. 376 U.S. 398, 401 (1964). Alfred Dumhill of London. Inc. v. Republic of Cuba, 425 U.S. 682 (1976) (White J. plurality opinion). W.S. Kirkpartick \& Co.. Inc. v. Environmental Tectonics Corp., 110 S. Ct. 701 (1990) (Act of State doctrine does not bar United States court from considering whether procurement of military contracts by United States company from government of Nigeria through alleged bribery violated United States antitrust and racketeering laws).

In re Japamese Elec. Prod. Antirnust Litig., 723 F.2d 238, 315 (3d Cir. 1983) (defense of sovereign compulsion does not apply in American television manufacturers ${ }^{\circ}$ antitrust action against Japanese manufacturers because allegedly predatory prices were not determined by the Japanese government), rev'd on other grounds sub. nom Matsushita Elec. Indus. Co. v. Zenith Radio Corp., 475 U.S. 574 (1986); Mannington Mills v. Congoleum Corp., 595 F.2d 1287, 1293 (3d Cir. 1979) ("Where govemmental action rises no higher than mere approval. the compulsion defense will not be recognized. It is necessary that foreign law must have coerced the defendant into violating American antitrust law."). Accord, United States Department of Justice. Antimust Division. Antrust Enforcement Guidelines for International Operations. \$ 6 (1988).

317 U.S. 341 (1943).

Southern Motor Carriers Rate Conference, Inc. v. United States, 471 U.S. 48 (1985) [hereinafter "Southern Motor Carriers"]. 
"state action" doctrine would protect allegedly anticompetitive actions pursuant to foreign authorization.

Occasionally, courts considering the Act of State and Foreign Sovereign Compulsion defences in cases involving alleged foreign conspiracies have drawn analogies to the state action defence. ${ }^{123}$ The state action doctrine has not been directly applied, however, to preclude consideration of the validity of the acts of a foreign state or of private parties pursuant to the law of a foreign state.

Nevertheless, it has been suggested that the rationale of the decision in Southern Motor Carriers Rate Conference, Inc. v. United States, ${ }^{124}$ might have undermined the compulsion requirement of the Foreign Sovereign Compulsion defence. ${ }^{125}$ In Southern Motor Carriers, the Court held that the Parker doctrine immunized private conduct undertaken pursuant to state law even where the conduct was not compelled, provided the actions were authorized under a "clearly articulated and affirmatively expressed" state policy and the state actively supervised the conduct. It could be argued that private conduct, undertaken pursuant to the clearly articulated and affirmatively expressed policy of a foreign sovereign which is actively supervised by that government, likewise ought to be exempt from United States antitrust scrutiny, even though such conduct is not compelled.

It is unlikely that a court would adopt the Southern Motor Carriers rationale, however, to exempt price pool arrangements maintained pursuant to Alberta law from antitrust scrutiny under a modified Foreign Sovereign Compulsion defence. The state action doctrine at issue in Southern Motor Carriers is based on the premise that the federal government should not interfere with the authority of states "to regulate their domestic commerce." ${ }^{126}$ The United States Supreme Court has emphasized that the state action defence is justified solely by considerations of federalism, and its protection is limited to actions taken pursuant to the authority of the states. ${ }^{127}$

By contrast, the doctrines of Act of State and Foreign Sovereign Compulsion are based on considerations of the separation of powers among the branches of the federal government. Under the Act of State doctrine, a court may abstain from exercising jurisdiction if to do so would hinder the Executive in the exercise of foreign policy. ${ }^{128}$

Industrial Investment Der. Corp. v. Mitsui \& Co., Lid., 594 F.2d 48 (1979) (Act of State doctrine did not preclude consideration of alleged conspiracy to exclude plaintiff from developing Indonesian Timber from export to the U.S.); Himt v. Mobil Oil Corp., 550 F.2d 68 (2d Cir.) (Act of State doctrine precluded consideration of alleged conspiracy to induce nationalization by Libya of petroleum extraction rights of plaintiff as this would entail examination of the validity of the Libya action), cert. denied, 434 U.S. 984 (1977).

124. Supra, note 122 at 48.

125. See, e.g., American Bar Association, Section of Antitrust Law, Antitrust Law Developments (2d), Second Supplement at IX-21, 22 (1988).

126. Supra, note 122 at 56.

137. City of Lafayette v. Lonisiana Power \& Light Co., 435 U.S. 389 (1978) (actions of municipal government not exempt unless taken pursuant to state authority).

12x. W.S. Kirkparrick v. Environmental Tectonics Corp., supra, note 119. 
It is thus likely that a court would conclude that the federalism-based state action doctrine should not be applied to questions involving private conduct pursuant to foreign law because it does not serve the same policies that support the Foreign Sovereign Compulsion defence. ${ }^{129}$

It is possible that a United States court would decline to exercise jurisdiction over any antitrust case based on the existence of a supply pool and operating under Alberta law based on considerations of international comity. Comity is "the recognition which one nation allows within its territory to the legislative, executive or judicial acts of another nation." ${ }^{130}$ Arguably, a United States antitrust suit complaining of cooperation among Canadian gas producers pursuant to Canadian law would interfere with the right of Canada to determine how best to manage its national resources and an American court should thus decline to hear such a suit. Such a result is unlikely, however, as the deregulation of natural gas in Canada was designed to encourage price competition. Further, an antitrust plaintiff probably would allege agreements among producers that went beyond those authorized or encouraged by Canadian law.

Ironically, if the recent amendments to the NGMA and the NGMR are seen to effectively mandate the continuance of existing price pool arrangements and establish the price at which gas can be exported under netback pricing agreements, the exposure of Canadian aggregators and producers to United States antitrust liability would be substantially reduced. The Act of State Doctrine would probably preclude an inquiry into the legality of the price pool system under United States antitrust law if the wellhead price or the export price of Alberta gas is set by the province of Alberta. ${ }^{31}$ To decide the case, the United States court would be called on to examine the validity of an act of the Alberta government, fixing gas prices at supracompetitive levels, under United States antitrust laws. This is precisely the sort of inquiry the Act of State Doctrine was designed to preclude.

Accord. Department of Justice. Antitrust Division, Enforcement Guidelines for International Operations. \$6 (1988).

1.41. Hilton v. Guyot, 159 U.S. I13, 164 (1895). The Third Circuit in Manningron Mills suggested a number of factors to be considered in deciding whether, in the interest of comity, a court should decline to exercise jurisdiction:

1. Degree of conflict with foreign law or policy:

2. Nationality of the partics;

3. Relative importance of the alleged violation of conduct here compared to that abroad;

4. Availability of a remedy abroad and pendency of litigation there;

5. Existence of intent to harm or affect American commerce and its foreseeability;

6. Possible effect upon foreign relations if the court exercises jurisdiction and grants relief;

7. If relief is granted, whether a party will be placed in the position of being forced to perform an act illegal in either country or be under conflicting requirements by both countries;

8. Whether the court can make its order effective:

9. Whether an order for relief would be acceptable in this country if made by a foreign nation under similar circumstances; and

10. Whether a treaty with the affected nations has addressed the issue.

595 F.2d at 1297-98.

13. O.N.E. Shipping Lid. v. Flota Mercante Grancolombiena. S.A., 830 F.2d 449 (2d Cir. 1987) (2-1) (Act of State Doctrine precludes inquiry into alleged antitrust violations arising from foreign cargo preference laws). 
A closer case would be presented if the amendments mandate a continuance of price pools, but do not effectively set the price at which Canadian gas could be exported. To the extent that merely participating in the voting process to determine netback prices creates exposure to United States antitrust liability, the amendment would protect the pool participants because aggregators and producers would be compelled to participate in the price pool. Such legislation would not, however, immunize a horizontal agreement among producers over how to respond to an aggregator's bid.

\section{FREE TRADE AGREEMENT}

The Canada-United States Free Trade Agreement became effective on January 1, 1989. The FTA is intended to implement the freest possible bilateral trade in energy, including non-discriminatory access for the United States to Canadian energy supplies and secure access to United States markets for Canadian energy. It is rather ironic that while one of the objectives of the FTA is fair competition between United States and Canadian goods, ${ }^{132}$ the FTA itself looms ominously over an energy sector in which free trade was already a virtual reality.

Between 1985 and 1989, a series of policy and regulatory changes in both Canada and the United States established a market orientation to bilateral energy trade. The advent of the FTA has only added fuel to the fire of the arguments of discrimination and equity that characterized the deregulation process. Chapter 9 of the FTA deals specifically with trade in energy, although such trade is also affected by a number of other provisions having general application. Significantly, there is no mention in the FTA of transportation. Article 902 affirms pre-existing Canadian and United States rights and obligations under the General Agreement on Tariffs and Trade ("GATT") with respect to prohibitions or restrictions on bilateral trade in energy goods, including a prohibition on minimum export or import price commitments. Export taxes are precluded by Article 903 , unless the tax is also maintained on energy destined for domestic consumption.

Article 904 provides for the placement of restrictions on the export of energy only where such a restriction would be otherwise justified under certain provisions of GATT and only if the restriction does not reduce the proportion of energy exported to the other party relative to the proportion exported prior to the imposition of the restriction. Restrictions that would impose a higher price for exports than for domestic consumption are prohibited. Further, any restriction must not require the disruption of normal channels of supply or normal proportions among different energy goods.

The sanction for energy regulatory actions that allegedly violate the FTA is intergovernmental consultation, as particularly described in Article 905 which states that should "either Party consider that energy regulatory actions by the other Party [will] directly result in discrimination against its energy goods inconsistent with the principles of [the] Agreement, that Party may initiate direct consultations with the other party." While the FTA therefore recognizes both the importance of, and the potentially disruptive 
role to be played by, the various United States and Canadian regulatory agencies, it leaves intact the existing and somewhat complicated regulatory framework on both sides of the border, allowing only for "discussion" between governments as a means of resolving conflict. Discourse, however, may prove insufficient, particularly when viewed in light of the recent legislative proposals in both countries. The United States Congressional effort to transfer jurisdiction over natural gas imports from the Department of Energy ("DOE") to the FERC so as to assure more exacting scrutiny of the import process, and the action of the Alberta government in amending the NGMA to extend the term of the existing netback agreement both suggest that FTA issues are likely to arise with frequency in the future, as the United States and Canadian governments are confronted with the need to maintain existing and vital transborder contractual supply relationships while heeding domestic pressures.

Unfortunately, because of the nebulous language of the FTA and the intention inherent in that document of preserving the status quo, the United States and Canadian regulatory agencies are likely to continue to operate autonomously, developing different agendas and pursuing incompatible objectives.

What are the FTA implications of the presently developing situation in California? One issue is whether the Alberta amending legislation permitting the extension of the netback pricing agreement will be construed as setting the price to be paid under the contracts. In such event, the legislation would be in clear contravention of the GATT principle affirmed in Article 902 of the FTA which states that no party shall require a minimum export price.

A recent decision of the NEB that was challenged on the basis that it set a minimum export price may serve to indicate the sensitivity of this issue. ${ }^{1.33}$ The NEB had denied five export licences on the ground that the proposed exports would be unlikely to provide "net benefits" to Canada. The Market-Based Procedure used by the Board in making its decisions included a benefit-cost analysis. The applicants sought leave to appeal to the Federal Court of Appeal and also asked the NEB to review its decision. One contention of the applicants was that the benefit-cost analysis amounted to the imposition of a minimum export price, contrary to the FTA. Before the matters could proceed to the courts, the NEB indicated that it would reconsider its decision, but it first launched a new proceeding to review the usefulness and validity of benefit-cost analysis as a factor in the Market-Based Procedure for determining whether exports of natural gas are in the public interest. ${ }^{134}$ Many submittors to the proceeding suggested that the use of benefit-cost analyses is or could be inconsistent with the FTA, ${ }^{1.35}$ but the NEB concluded that the question of its FTA jurisdiction was "beyond the scope of [the] proceeding."136 Nevertheless, the Board went on to decide that it would no longer use benefit-cost analysis in its gas export licensing procedures.

See National Energy Board Reasons for Decision Review of Certain Aspects of the Market-Based Procedure, GHW-4-89, March 1990.

GHW-4-89 at $8 \mathrm{ff}$.

GHW-4-89 at 10. 
The decision to eliminate the use of cost-benefit analysis was shortly followed by a reconsideration and approval of the five previously denied export applications. At the time, there were indications that if the NEB did not reverse its denial of the export licences, the United States State Department was prepared to file a complaint under the FTA alleging that the use of the benefit-cost test was a minimum export price that violated the FTA. ${ }^{137}$

The Alberta legislation that extends netback pricing agreements but maintains the relatively flexible price determination mechanism makes a contravention of the FTA less apparent. At one level it could be argued that market forces will continue to determine the price charged for the exported good. The FTA does not require that prices must be equal for exported and domestically consumed energy goods, but requires that neither party may increase the price of exported energy by levying taxes, duties or other charges without applying such tax, duty or charge to domestic energy. It could also be argued that the extension of the netback pricing agreement does not amount to a quantitative restriction since the quantities of gas available to the California consumers will presumably not diminish from what was available prior to the amending legislation. The contrary argument would be that while the Alberta intervention may not be specifically characterized as a tax, duty or charge or as a quantitative restriction, the larger principle of equal treatment will be violated since the legislation will effectively apply only to A\&S after the designation order is issued.

The general principle of equal treatment, while not absolute, arguably permeates the character of both the FTA and GATT. For instance, by Article 904 certain restrictions justified under GATT may only be introduced if the proportionality of export to total supply is maintained, and Article XX of GATT states that certain justified restrictions on trade are:

(s)ubject to the requirement that such measures are not applied in a manner which would constitute a means of arbitrary or unjustifiable discrimination between countries where the same conditions prevail or disguised restriction on international tradc...."

Article 502, upon which the Canadian Producer Group relied in CPUC proceedings, could also be used to challenge the Alberta legislation with the assertion that the treatment afforded to gas destined for California is less favourable than the most favourable treatment accorded by Alberta to gas in that province.

Finally, the strongest criticism of the Alberta amending legislation may not be addressable under any specific provision of the FTA but on a more general basis. The degree of impairment of freely negotiated contracts that would be wrought by the governmental intervention would arguably contravene the very "spirit" of the FTA. The Alberta government may be able to rationalize that it has not broken the "letter" of the

13. J.L. Cohen, and D.A. Holgate, "Impact of the Free Trade Agreement on Canada - U.S. Oil and Gas Trade: The Canadian and United States Experience" (1990) 8 Oil \& Gas Law and Taxation Review' at 121-24. 
FTA, but it certainly will expose itself to allegations that it has taken a step backward in the development of energy free trade.

On the other side of the border, the CPUC appears to be struggling with the issue of the proper treatment of Canadian gas contracts. Such struggle has manifested itself in inconsistencies of position and approach. For example, in the Procurement Decision, the CPUC recognizes the need for "compromise . . . to maintain good trade relationships with Canada, relationships which will benefit Canadian and Californian alike." ${ }^{138}$ As a consequence, the Procurement Decision incorporates the provisions of the Access Agreement, thereby guaranteeing, at least until August of 1994, the continued viability of the A\&S contracts. In addition, the CPUC has recognized that it lacks the jurisdiction to in any way alter the contracts entered into by $A \& S$ and the Canadian producers. ${ }^{139}$ On the other hand, the Procurement Decision and the Capacity Brokering Decision make it clear that the CPUC would like to see Canadian gas purchase contracts renegotiated years prior to the expiration of the Access Agreement. Further, on February 21, 1991, the CPUC issued decision 91-02-040 (the "SPURR Decision"), pursuant to which core customers ${ }^{140}$ of utilities may aggregate loads from various core facilities, enabling the customers to procure gas on their own from supply sources of their choice. It has been argued by Canadian producer groups that, through SPURR and the Capacity Brokering Decision, the CPUC intends to do what it could not immediately accomplish in the Procurement Decision, namely, abrogate the Canadian supply contracts presently in existence.

While abrogation of such contracts may not in fact result, and while renegotiation of Canadian contract terms may make these contracts more competitive, the CPUC approach, with its restrictive focus, is troubling from an FTA perspective. The CPUC clearly does not appreciate the integral role played by the NEB in effecting the contractual arrangements. Similarly, the CPUC has tended to view actions of PG\&E and its obligations in isolation, rather than as only one segment of an interdependent contractual chain, ${ }^{|4|}$ a chain for which the NEB and the DOE, as well as the CPUC, have expressed support. It is precisely this narrow viewpoint, and the lack of transborder cooperation that necessarily flows from such a viewpoint, that the FTA is intended to discourage.

\section{CONCLUSION}

Recent developments simply reaffirm that the sale of Alberta gas in United States markets will continue to raise controversial legal issues. Political, legislative and regulatory actions on both sides of the border can be expected to raise constitutional, antitrust and free trade issues that will have an impact on the enforceability of gas sale

1.3. Procurement Decision at 66.

134. Ibid.

140. Core customers are small utility customers, such as residential customers and schools that are dependent upon a particular energy supply source and thus are "captive" to the utility.

141. As the CPUC stated in the Procuremem Decision, "PGT's contractual obligations to A\&S are. like A\&S' obligations to Canadian producers, not guaranteed by PG\&E's ratepayers." Procurement Decision at 66. 
contracts. Regrettably, it must be concluded that the issues presently facing the industry are of sufficient magnitude and difficulty that they will not be put to rest without recourse to some forum of dispute resolution - "discussions" under the FTA, regulatory litigation or the courts. 